\title{
Corporate Responsible Behavior in Multinational Enterprise
}

\author{
Andersen, Torben Juul
}

Document Version

Accepted author manuscript

Published in:

International Journal of Organizational Analysis

DOI:

10.1108/IJOA-12-2016-1098

Publication date:

2017

License

Unspecified

Citation for published version (APA):

Andersen, T. J. (2017). Corporate Responsible Behavior in Multinational Enterprise. International Journal of Organizational Analysis, 25(3), 485-505. https://doi.org/10.1108/IJOA-12-2016-1098

Link to publication in CBS Research Portal

\section{General rights}

Copyright and moral rights for the publications made accessible in the public portal are retained by the authors and/or other copyright owners and it is a condition of accessing publications that users recognise and abide by the legal requirements associated with these rights.

Take down policy

If you believe that this document breaches copyright please contact us (research.lib@cbs.dk) providing details, and we will remove access to the work immediately and investigate your claim. 


\section{Corporate Responsible Behavior in Multinational Enterprise Torben Juul Andersen}

Journal article (Accepted manuscript)

CITE: Andersen, T. J. (2017). Corporate Responsible Behavior in Multinational Enterprise. International Journal of Organizational Ana/ysis, 25(3), 485-505. D01: 10.1108/IJOA-12-2016-1098

This article is [? Emerald Publishing Limited 2017 and permission has been granted for this version to appear here: https://research.cbs.dk/en/publications/corporate-responsible-behavior-in-multinational-enterprise.

Emerald does not grant permission for this article to be further copied/distributed or hosted elsewhere without the express permission from Emerald Group Publishing Limited.

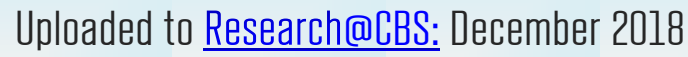




\title{
Corporate Responsible Behavior in Multinational Enterprise
}

\author{
Torben Juul Andersen \\ Copenhagen Business School \\ Department of International Economics and Management \\ Porcelænshaven 24A, \#3.78 \\ DK-2000 Frederiksberg \\ Denmark
}

Email: tja.int@cbs.dk

Phone: +45 3815-2572

December 2016 


\title{
Corporate Responsible Behavior in Multinational Enterprise
}

\begin{abstract}
This study analyzes how leadership values appeared to influence corporate responsible behavior in a large complex multinational organization with ethical principles imposed through the example of concrete actions taken to deal with regulatory, environmental and international labor issues. It shows how increasing functional specialization, multinational diversity, and business acquisitions challenged adherence to the core values and called for more formal approaches to enforce them. Core values expressed in decisions to invest in positive economic externalities enhanced a reputation of trust, accountability and reliability that facilitated sustainable collaborative solutions to emerging issues.
\end{abstract}

$\underline{\text { Key words: }}$ Economic externalities, Leadership values, Multinational diversity, Organizational culture, Stakeholder theory, Values-based management 
"The key is for private enterprises to behave responsibly, both at home and abroad, so that growth can flourish without damaging the environment or social fabric of the countries where they operate"

[Bill Witherell and Maria Maher, OECD Directorate for Financial, Fiscal and Enterprise Affairs]

\section{Introduction}

A stringent pursuit of responsible behavior implies that the firm does no harm to the environment and the social structure of society. This is virtually impossible to achieve since business development inevitably will influence the surrounding nature as well as economic transactions affect the people involved, so the final evaluation depends on the ethical beliefs of the affected stakeholders (Harrison and Freeman, 1999). However, the challenge of responsible behavior increases exponentially in organizations with many diverse stakeholders operating in highly complex multinational contexts.

Already Bernard (1938) noted that ethical conduct is embedded in supportive social norms and derive from the morality of executive governance where responsible behavior is influenced by the morale principle of leadership (De Hoogh and Den Hartog, 2008; Trevino, 1989). However, the role of executive leaders as instigators of corporate responsible behavior and sustainable performance has not been studied in the context of complex multinational organizations (Siegel, 2014; Walden and Balven, 2014).

Inconsistent empirical results in leadership research further question the current state of the field (Van Knippenberg and Sitkin, 2013). Somewhat at odds with prior studies, Hooijberg, Lane and Deversé (2010) found no relationship between values and leader effectiveness and Andersen (2011) did not trace any managerial effects on multinational risk outcomes. This could be due to incomplete definitions and measures, a disregard for basic leadership contingencies, or an inability 
to discern long-term effects in cross-sectional analysis. This pinpoints a need for more granular longitudinal studies of complex internationalizing organizations to gain deeper insights. To this end, we studied corporate responsible behavior in a multinational enterprise to uncover how leadership dealt with unexpected ethical challenges over time.

The study was inspired by practitioner-based theory building drawing on evidence from involved managers (Bartunek, 2007; Nielsen, 2009). It adopted a positivist case-study approach (Yin, 2003) where performance is seen as the outcome of managerial interventions responding to emerging challenges guided by the core values of the corporation (Hanke and Stark, 2009; Mintzberg and Waters, 1985). It also considered possible influences of storytelling (Boje, 2001; Brown, Gabriel and Gherardi, 2009) and retrospective sense-making (Weick, Sutcliffe and Obstfeld, 2005) soliciting information from multiple managerial and executive sources.

The paper is organized as follows. First, theoretical rationales for responsible behavior are derived from values-based, stakeholder and economic externality arguments as a deductive foundation for the case study. Then the practitioner-based theory building, the case-study approach, and critical narrative perspectives are outlined before major corporate events, their ethical challenges, and eventual resolutions are presented and analyzed. Finally, the main findings are contrasted to prevailing theory to generate insights about the relationship between leadership, core values, and corporate responsible behavior and the implications for sustainable outcomes in multinational enterprise.

\section{Theoretical background}

Responsible behavior tries to avoid adverse effects from corporate actions on the surrounding natural and social environments represented by major stakeholders (Harrison and Freeman, 1999). Campbell (2007) defines corporate responsible behavior as not to "knowingly do anything that 
could harm their stakeholders" and "if they do cause harm to their stakeholders, they must rectify it whenever the harm is discovered" (p. 951). See Carroll (1999) for a more complete account of the corporate responsibility concept. Leaning on studies of ethical decision making (e.g., Trevino, 1986), we deduce that corporate responsible behavior is a function of the moral principles, or core values, pursued by the leadership typically exemplified by the CEO (Figure 1). Hence, leadership values supposedly derive from the morality of top management and earn confidence and loyalty through role modeling (De Hoogh and Den Hartog, 2008).

- - - Insert Figure 1 about here - - -

It is argued that "values are the bedrock of any corporate culture" (Deal and Kennedy, 2000: p. 21) and provide guidance to all actors in the organization. Corporate culture can be seen as an alternative to formal contracts specifying duties and details on correct procedures. The cultural norms are unwritten contracts "broad but clear enough to specify optimal employee action in the face of contingencies too difficult to foresee" (Camerer and Vepsalainen, 1988: p. 117). Hence, culturally embedded values can help decision-makers deal with unexpected conditions. However, they are not merely contractual relationships but are linked to the personal acts of leaders as moral exemplars (Burns, 1978). The leaders are defined by their moral impact on followers providing inspiration through trust, respect and admiration (Bass, 1985; Bass and Aviolio, 1994; Bass and Steidlmeier, 1999).

Schein (2004) argues that corporate culture derives from: "(1) the beliefs, values, and assumptions of founders, (2) learning experiences of group members as the organization evolves, and (3) beliefs, values, and assumptions brought in by new members and leaders.” (p. 225). When the founder ages, traditional values are challenged as new leaders come in and replace the inherited legacy. This can be an opportunity. As Shein (2004) notes: "treasured values will be eroded if new 
CEOs don't adhere to them; on the other hand, it makes it possible for the organization to make necessary changes in its goals and means, and, if necessary, to change elements of the culture" (p. 273). The values are enforced by concrete actions and influence the responsible behaviors embedded in the corporate culture.

All the while, Schein (2004) explains how organizational subcultures can arise as a consequence of corporate growth where leadership is challenged in its ability to oversee extensive foreign activities. The organization becomes a coalition of increasingly specialized entities. He lists a number of factors that create divergent subcultures including functional differentiation, geographical dispersion, business diversification and corporate division (Schein, 2004). Accordingly, empirical studies find that social behaviors are influenced by divergent values and power structures across national cultures (Waldman, Sully de Luque, Washburn and House, 2006). Management practices at different hierarchical levels and geographical regions can also create pockets of diverse behaviors (Campbell, Eden and Miller, 2012; Schaubroeck, Hannah, Avolio, Kozlowski, Lord, Trevino, Dimotakis and Peng, 2012). Hence, the effect of leadership values on corporate responsible behavior is challenged by diverse national cultures and by functional, geographical, and business diversification.

Corporate responsible behavior is supposed to have positive performance implications. Behaving responsibly means that corporate actions prioritize stakeholder relationships without inflicting harm on the environment. Values-based management provides a balanced view on stakeholder interests to avoid negative economic externalities. According to values-based management one of the principal leadership tasks is to consider stakeholder concerns associated with resource committing decisions (Anderson, 1997). Hence, imposing proper values can facilitate collaboration with key stakeholders towards common ends. These core values consist of 
shared beliefs embedded in the corporate culture that influence how actions are taken based on informal guidelines (Wieland, 2005). This corresponds to Simons' (1995) conceptualization of belief systems that convey core values to guide and inspire search for solutions and opportunities in the firm. ${ }^{1}$

Stakeholder theory argues that business is about "how customers, suppliers, employees, financiers (stockholders, bondholders, banks, etc.), communities, and managers interact and create value" (Freeman, Harrison, Wicks, Parmar and De Colle, 2010: p. 24). ${ }^{2}$ The economic benefits may derive from improved relationships through knowledge sharing and creative interactions (Don and Quigley, 2014) in firm-specific value-creation (Wang, Barney and Reuer, 2003). It can also facilitate collaborative solutions if unexpected events occur (e.g., Husted, 2005; Kytle and Ruggie, 2005). That is, good stakeholder relations may sustain corporate performance by satisfying common interests and avoiding conflicts.

When a business fails to account for the full costs of activities, or create incremental benefits, we encounter economic externalities. A negative externality arises when, for example, a firm pollutes the environment without compensating those affected by it. A positive externality may occur when a firm invests in activities with positive societal spill-over effects. Negative economic externalities impose cost on other stakeholders and create a potential for future conflicts. The firm has immediate short-term gains but creates long-term liabilities where those adversely affected can seek compensation for damages. Conversely, if a firm invests in positive externalities it incurs immediate expenses but creates goodwill for potential longer-term benefits. Hence, adopting responsible behavior reduces the likelihood of future conflicts that could threaten economic

\footnotetext{
${ }^{1}$ Simons (1995: p. 167) argues that core values heeded by organizational members are rooted in history, traditions and the values of the firm's current senior managers.

${ }^{2}$ A simple definition of the firm's major stakeholder groups is: "any group or individual who can affect, or is affected by, the achievement of a corporation's purpose" (Freeman, 1984: p. vi).
} 
viability. These rationales explain why corporate responsible behavior can lead to better long-term performance.

\section{Methodology}

The study seeks to gain insights on how corporate leaders may drive responsible behavior to sustain corporate performance outcomes in a complex multinational organization in view of a proposed theoretical model. The single-case study method is considered suitable for an exploratory study of contemporary phenomena (Yin, 2003) where decisions evolve over time and their consequences are observed, or recollected, by engaged corporate executives. It represents an opportunity to use unique inside sources of hands-on insights and experiences from a number of central stakeholders around a large multinational organization representative of the research focus. The study was conducted as an academic-practitioner collaborative effort probing experienced executives that often observe complex situations from a more holistic business perspective (Bartunek, 2007). We collected and analyzed executive narratives of relevant actual events over a period of multiple years 2012-15 (Barry and Elmes, 1997; Dutton Ashford, O’Neill and Lawrence, 2001) as a basis for practitioner-based theory building (Nielsen, 2009). The observed phenomena were then interpreted in the context of prevailing theory to develop new deeper understanding for management practice.

To safeguard valid assessments we used informants with industry expertise from years of direct involvement and deep understanding of international business practices (Yin, 2003). We obtained information from multiple respondents and discussed various case situations and events in various managerial audiences to test facts and discern perceptional biases (e.g., Bazerman and Moore, 2009; Lovallo and Kahneman, 2003). We taped interviews and conversations and crosschecked handwritten notes from meetings against recordings to ensure a high level of reliability. 
The initial interviews were also transcribed and cross-checked. To ensure internal validity we compared reported events across different internal informants and checked against corporate documents, and press releases as well as contemporary newspaper articles and published books. We additionally interviewed key external stakeholders with direct involvements in the reported events to obtain their perspective and thereby gain external validity.

Notwithstanding the various attempts to set up a scientific design, we also realize that gathering case material and data from ex-post recollection of events can be perceived as a pseudopositivist approach ignoring potential influences of organizational storytelling (e.g., Brown, Gabriel and Gherardi, 2009; Gabriel, 1991; Boje, 2001). Hence, we further discuss the case

analysis and findings from the view of retrospective sense-making (Weick, Sutcliffe and Obstfeld, 2005 ) and influences of organizational storytelling and evolving narratives.

\section{The corporate context}

The A. P. Møller - Mærsk (APMM) group can trace its roots to 1904 when Arnold Peter Møller at age 27 incorporated Dampskibsselskabet Svendborg and later a sister company Dampskibsselskabet af 1912. A. P. Møller’s son, Mærsk Mc-Kinney Møller, was born in 1913. The business activities expanded steadily and Mærsk Mc-Kinney Møller became co-owner of the shipping company in 1940. A. P. Møller had a patriarchal leadership style with strong core values many of which have prevailed until today. Employees were expected to perform and slacking was not accepted. Competence, wholehearted effort and loyalty earned respect and was rewarded. As co-owner Mærsk Mc-Kinney Møller was mandated to manage the company fleet from New York during the Second World War for as long as Denmark was occupied. The concern for 'Constant Care' mentioned so often in the company (Hornby, 1988) dates to this time where A. P. Møller 
sent a letter to Mærsk Mc-Kinney Møller advising him: "that no loss should strike us that can be avoided through constant care", 3

Company activities expanded in the decades of post war reconstruction and industrial growth. When A. P. Møller died in 1965, Mærsk Mc-Kinney Møller became CEO of the group. The gradual abolishment of import restrictions and tariff barriers increased global trade and gave opportunities for growth in the international shipping business. The container technology revolutionized the seaborne line traffic. APMM was leading the way and established terminals in key locations around the world. The company's own shipyard made advanced container ships and oil tankers. The group also expanded into other business activities including retail distribution, oil exploration and air transportation.

Mærsk Mc-Kinney Møller resigned as CEO in 1993 and Jess Søderberg took over. The APMM group continued to expand the container-line traffic as globalization implicated extensive movement of goods between the continents. The APMM group acquired two friendly competitors Safmarine and Sea-Land in 1999 extending their network in Europe-Africa, North and Central America. Mærsk Mc-Kinney Møller retired as Chairman in 2003 and was replaced by Michael Prahm Rasmussen. APMM acquired the Anglo-Dutch worldwide container shipping line $P \& O$ Nedlloyd in 2005 to forge a leading market position but the post-merger integration was a challenge. Jess Søderberg was replaced as CEO in late 2007 by Nils Smedegaard Andersen, until then CEO of Carlsberg A/S and non-executive member of the APMM board. The maritime industry was severely hit by the global economic crisis with contracting trade volumes and low freight rates. In response, the new CEO focused the organization on cost consciousness and

\footnotetext{
${ }^{3}$ These historical developments are described in various corporate sources, business magazines, newspapers and management books including Benson, Lambek and Ørskov (2004), Cortzen (2003), Lunde (2008), Lindholm and Stokholm (2011) among others.
} 
resourcefulness divesting marginal activities to trim the business portfolio. The key events in the corporate development of the APMM group are summarized in Figure 2.

- - - Insert Figure 2 about here - - -

\section{Leadership values}

In the early 1990s the company had strong cultural traits dating to the founder A. P. Møller emphasizing decent behavior, honesty and respect. These values had never been written down but permeated communication from Mærsk Mc-Kinney Møller to business associates as the pillars of management thinking across the organization (Cortzen, 2003). There were no formal policy documents but the corporate values were reflected in executive decisions and written instructions. They became an engrained way of thinking, acting and behaving and were in the spines of corporate managers advancing through the ranks.

The core values were enforced through concrete actions. For example, APMM decided to build double hull tankers right after the Exxon Valdez oil spill in Prince William Sound, Alaska, on March 24, 1989 to replace the entire company fleet of oil tankers. This overhaul was accomplished by 1993. However, the more costly ships did not earn a return for a long time because most charterers continued to opt for cheaper single hull transport. Things did not change until the international maritime conventions were changed in favor of double hull oil cargos after a major environmental catastrophe. On December 12, 2000 the Erika, a tanker chartered by Total Fina, spilled around 11 million liters of oil off the French Atlantic coast. Although the spill was around a fourth the size of the Valdez incident, a heavy winter storm turned it into an ecological disaster affecting a 350 kilometer coast line killing around 100,000 seabirds.

As a consequence, new international maritime conventions scheduled a gradual phasing out of single hull tankers from 2002 and created a two-tier freight rate system with special rates for 
double hull tankers. ${ }^{\mathrm{i}}$ By that time the APMM group only had double hulled ships and was not faced with the economic challenge of renewing the fleet. So, a combination of foresight, luck and responsible behavior eventually paid off after a decade. In the meantime charterers would chose the lowest single hull rates to save costs in stark contrast to official statements about environmental concerns expressed in "glossy brochures". This observation made the APMM leadership pledge not to make public announcements but rather instill in employees to "do the right thing" and be fair in corporate relations. The mantra was that there are limits to what one can deliver, but if a commitment is made "you must live up to your promise". In this context, communication and public relations were seen as means to retain good relations building trust from a reputation of honesty and accountability. These core values guided the decisions in business units and field offices honing an entrepreneurial spirit of timely responses serving the best interest of the company (Jensen, 2014).

\section{Executive decisions}

The global shipping industry has always been governed by national restrictions and complicated international treaties ${ }^{\mathrm{ii}}$ making good relationships to public authorities essential. Having the most modern fleet does not guarantee access to national harbors, but good relations to governments, regulators, trade associations, business partners and local customers do. By the late 1990s global shipping continued to grow as did activities in retail distribution, oil exploration and air transportation. But the increasing complexity of the expanding group created new exposures. Hence, the company was taken by surprise in 2000 when its airline business was charged with infringements to the European competition laws. ${ }^{\text {iii }}$

The APMM subsidiary Mærsk Air and SAS (Scandinavian Airlines System) had filed a cooperative agreement with the European Commission in late 1998 informing that they engaged 
in code-sharing and exchanged frequent flyer benefits among customers. However, inspections conducted by the Commission in June 2000 revealed a more restrictive agreement with noncompete clauses on certain inter-European flights. Mario Monti, the Competition Commissioner at the time, stated that: "This is a clear case of two airlines sharing markets illegally to the detriment of passengers." The incident showed a lack of regulatory compliance with huge potential fines that could hurt their reputation. The corporate leadership realized that the head of the airline business thought the cartel agreement would benefit the company, even though it was not in the best interest of the group. They decided to work with commission officials to get things right.

After this incidence educational programs were arranged throughout the organization to sensitize employees to regulatory requirements and the need to comply with them. The intent was to make the organization learn from the bad experience and improve internal practices. There was openness about the mistake and a willingness to make changes to avoid similar incidents. The compliance programs were extended beyond competition rules to comprise regulatory issues in general.

Another chain of events took place the following years related to labor conditions among truck drivers at company locations in certain US and Central American ports. The terminals in Miami were blocked for ten days in summer 2004 by independent truck drivers protesting against increasing fuel prices and long un-compensated waiting hours. Complaints about truck driver conditions in El Salvador, Honduras and Nicaragua emerged during the same period. In Honduras things escalated after the national Congress ratified the Central American Free Trade Agreement, imposing more competition among independent truck drivers and working against union interests. More than a thousand demonstrators assembled in Tegucigalpa to protest supported by the union 
for Honduras port truckers. ${ }^{4}$ Similar protests arose across Central America where events at times escalated.

Company activities at important terminals were affected by this turmoil caused by external events challenging the company's ability to service the container traffic. The incidents reflected indirect relationships between local governments, harbor authorities, labor unions and independent truckers with the company caught in the middle. External advisers would tell the company that it had no legal right to force unionized relationships whereas the unions requested that the company should influence things. It was in this context that representatives of the International Labor Organization (ILO) and the US teamsters turned up at the APMM annual general meeting in 2005 to protest against what they saw as the effects of a conscious corporate policy. These events culminated with the "Indian truck drivers" incident a few years later.

As part of the global container business the APMM group had invested in modern terminals agreement with the Mumbai harbor authorities that counted for roughly half of India's international container traffic. Global Terminals India (GTI) was established as a joint venture between Container Corporation of India Ltd. (CONCOR) and APMM as a $74 \%$ shareholder. $^{5}$ The GTI engaged a number of local trucking firms as subcontractors to handle transportation of containers. The terminal workers formed a local union as part of the Transport and Dock Workers Union (TDWU) but unionized workers were subsequently abducted and beaten. A competing union, Navi Mumbai General Kamgar Sanghatana, was formed around one of the subcontracting trucking firms followed by incidents of raw violence against TDWU members. The APMM group was accused

\footnotetext{
${ }^{4}$ Sindicato Nacional de Motoristas de Epuipo Pesado de Honduras (SINAMEQUIPH).

${ }^{5}$ CONCOR was incorporated in 1988 as a major inland rail transporter of containers operating by agreement with the Ministry of Railways that provides manpower to the company in accordance with formally approved objectives. That is, the company operates as a separate legal entity established by the Indian government.
} 
of tolerating violence against unionized workers failing to honor freedom of association. This development was aggravated further as large institutional investors among the company's major shareholders were influenced by environmental rating agencies that recorded the discrepancies. ${ }^{\text {iv }}$ These incidents created potential conflicts with major stakeholders and exposed the APMM group to a number of intricate issues with national political and legal ramifications for labor conditions upheld among overseas subcontractors.

Finding a suitable solution to these issues was complicated because it had to balance concerns for local employment conditions subjected to national legislation and competing union demands while securing trucking capacity to serve the business volume in the terminal. There was no quick fix to the problem and finding a resolution became a prolonged affair. The fact that international unions stood head to head with the company's board at the annual general meeting protesting with large banners shocked the leadership. As a consequence senior management decided to work with the unions if possible. To accommodate this, the company established an internal high-level group to interact with the unions. This group collaborated with the International Transport Workers' Federation (ITF) ${ }^{6}$ in London and, therefore, had an open dialogue with them when the issues arose in Mumbai.

\section{Impressions from key stakeholders}

The ITF relationship intensified around 2000 as the truck driver incident in El Salvador began to surface. This issue arose after the APMM acquired US based Sea-Land that had its own trucking subsidiaries in El Salvador. These operators were accused of using unfair lie detection methods in their hiring of drivers, which prompted conflicts with local unions. In the beginning corporate managers at APMM did not show much interest in these issues. They saw the APMM group as a

\footnotetext{
${ }^{6}$ ITF is the London-based umbrella organization for over 700 local transport workers' unions representing more than 4.5 million transport workers in 154 countries around the world.
} 
Danish company with good overseas relationships and did not really want to intervene in local affairs. They did not really see APMM as a multinational company. A meeting was set up in Copenhagen on Sept. 10, 2001 between APMM, ITF, the US Teamsters, the Rotterdam dock workers, and the Danish 3F Union to solve the problem. There was no immediate outcome from the meeting partly due to the $9 / 11$ incidence the following day that diverted management focus towards security concerns.

However, the need for ongoing dialogue was on the minds both among senior management at APMM as well as within the ITF circles. The $41^{\text {st }}$ Congress of the ITF in Durban in 2006 decided to form a global network with leading companies including APMM as one of the members. The company was invited by the ITF to be part of a global network group and they sent a positive reply within a week. Hence, a forum for ongoing dialogue was in place when the truck driver incident in Mumbai escalated in early 2007. ${ }^{\mathrm{v}}$

The subsequent discussions revealed different perceptions among corporate managers in the local, divisional, and headquarter-based entities in the APMM group. The regional managers did not consider the labor dispute to be their concern but saw it as industry relations to be handled by the business unit according to local law. The local managers did not understand why they could not just adhere to the local business practices. The incident was complex and seemed to be caused by one contracted firm that allegedly used violence to combat unionization of truckers with a number of drivers being abducted and beaten severely. The situation was complicated further when this subcontractor created its own union. Yet, the established unions held APMM responsible for engaging partners with unacceptable practices.

The violence raised concern among senior management at the terminal division in Hague that generally wanted APMM to be seen as a decent company. They wanted to do something while still 
pointing out that it was not strictly their legal responsibility. Eventually they put pressure on the contractors but it came to a head because the local unions required the reinstatement of dismissed truck drivers where some had been reemployed but not all of them. There was considerable confusion about the facts and unverified information was communicated by different sources. The local unions blocked the harbor facilities in protest. Unfortunately GTI took out an injunction against the pickets and lost their case in local court. However, they had not informed the terminal division in Hague about this legal move, which created frustrations among the senior executives. So, much learning seemed to go on in the APMM group as they tried to reconcile apparent differences between corporate, divisional and local managers.

The issue was eventually resolved through direct intervention by the terminals division to reinstate some of the dismissed drivers. To further a resolution, the ITF arranged meetings between GTI and the local union TDWU to discuss a way forward. But, this was followed by more violence. As a consequence, APMM headquarter executives agreed to meet with ITF in London to establish a "workers' rights committee" to resolve the local labor market issue. The first priority was to clarify the situation and determine who was organized in what unions. This turned out to be difficult to settle because the subcontractors were less than forthcoming with information. Yet, a final survey showed that a majority of drivers wanted to belong to TDWU. APMM agreed to abide by this result, so GTI wrote to all their subcontractors asking them to accept the drivers' right to organize with TDWU. When still nothing happened, APMM intervened directly to move things forward.

This was not easy because the company depended on the services provided by the various subcontractors who used their position of strength for own advantage. So, it was a challenge to gradually press the wrongdoers to change their behavior. It eventually came to a discussion about 
renegotiating the transport rates to compensate for the increased costs of unionization. The APMM group accepted higher rates provided the subcontractors did not increase their prices more than other unionized trucking firms. Hence, after a long, intense, and laborious process, the issues were cleared in March 2010 as the fruit of a collaborative effort between APMM and the ITF as arbitrator to the local unions.

Looking at these incidents the EIRIS internal reports reveal that APMM responded quickly to requests for information about the allegations that trade union rights were violated. Similarly, the unions were satisfied with the way the APPM group addressed the issues. As a consequence, the potential restrictions imposed by large institutional investors including the ATP evaporated with a positive assessment in the EIRIS watch report.

\section{Reactions at corporate headquarters}

The described incidents reflect the challenges of multinational operations across regions with different national norms, institutional frames and legal systems. They also show the difficulty of heeding universal values across a large and diverse organization operating in a highly complex and constantly evolving global environment. Outside pressures with respect to competition, the environment, freedom to unionize, etc., were visible but only surfaced gradually to become potential threats. That is, the business conditions were highly complex and evolved over time. Similarly, the underlying issues were resolved through ongoing interaction with important stakeholders over extended periods of time emphasizing the significance of good relations. However, expanded reach of corporate activities made local managers less attached to the core values. The corporate culture remained strong at headquarters but could no longer be taken for granted among 100,000 employees around the world. This caused various incidents reported by an 
attentive public press urging the corporate leadership to somehow reemphasize the core values. ${ }^{7}$ Mr. Mærsk Mc-Kinney Møller was cognizant of this and gathered the top 50 executives at his home when he retired as Chairman in 2003 to personally imprint the values in them all.

With a new top management team in place corporate guidelines and policies were introduced to express the 'Mærsk Values' (see Appendix 1). This was enhanced by formal guidelines specifying the core values with respect to responsible business behavior, working conditions, environmental concerns, societal engagement and human rights. ${ }^{8}$ The company established a corporate social responsibility department and signed the UN Global Compact in February 2009 committing to good social behavior. These efforts were backed by official sustainability reports informing about the company's performance in central areas like $\mathrm{CO}_{2}$ emissions, safety standards, waste disposal, recycling, human rights, corporate citizenship, etc. As stated by Annette Stube, Director of CSR: "The basic principles of being a responsible business are transparency and accountability. This means being open about our performance both when it's good and not so good, and clear on how we intend to handle it." The group CEO, Nils Smedegaard Andersen condoned this arguing that "good behavior is good business".

\section{Congruence with prevailing theory}

The study uncovers an organization where the founder A. P. Møller set the standards for ethical conduct enforced through encouragement, career advancements and moral principles embedded in concrete actions (Grojean, Resick, Dickson and Smith, 2004). These values were passed on by Mærsk Mc-Kinney Møller and made apparent in written instructions and concrete decisions, such

\footnotetext{
${ }^{7}$ Such reported incidents included, for example, allegations about poor working conditions in Chinese container production plants, use of dangerous pesticides in African plantations, etc. These cases reported on conditions in partly owned subsidiaries and thereby raised issues about the group's social responsibility for events and conditions at subcontractors and business partners in general.

${ }^{8}$ The 'Mærsk Fundamental Business Principles' were introduced in early 2007 and subsequently evolved into the 'Mærsk Principles of Conduct' and the 'The Mærsk Group's Group Policies'.
} 
as, investing in double hull tankers. The enforcement of values was challenged by the expanding reach of the organization across diverse national cultures and acquired companies. All the while the socio-economic environment was changing, e.g., with the UN Global Compact increasing a focus on good social behavior.

These accounts are consistent with the literature where Deal and Kennedy (2000) see values as the foundation of corporate culture that guides employees through ambiguous unprecedented situations (Camerer and Vepsalainen, 1988). It also illustrates how the example of leader actions personifies the morale conduct (Burns, 1978) and inspires followers (Bass, 1985). It captures Schein's (2004) notion of corporate culture deriving from the values of a founder, ongoing learning and influences from subsequent leaders. The case illustrates the leadership role of instigating values and corporate culture influenced by external factors (Gehman, Trevino and Garud, 2013). We also see the contours of corporate subcultures across acquired businesses and different geographical regions (Campbell, Eden and Miller, 2012; Schein, 2004). An extended multinational

presence exposed the organization to diverse cultural and institutional practices (Campbell et al., 2012) increasing the complexity of dealing with moral dilemmas. Overseas acquisitions exacerbated the complexities as the acquired business failed to match the APMM values while an increasing emphasis on global social responsibility raised the bar for ethical business conduct.

\section{Empirical evidence}

To validate the described exposures to increasingly complex multinational conditions, we counted the frequency of reported corporate events using content analysis (Tetlock, Saar-Tsechansky and Macskassy, 2008) using unbiased public media data (Uotila, Maula, Kiel and Zahra, 2009). The number of articles reporting incidents in APMM international operations during 1994-2014 was 
counted based on digitalized newspapers and wires collected by Infomedia ${ }^{9}$ from all primary national and regional news outlets. The incidents were classified according to the four "UN Global Compact" headings: Human rights, labor relations, environmental conditions and anti-corruption (see appendix 2) adding an extra heading to capture compliance incidents.

Search words ascribed to each subject heading were applied for a comprehensive search of 5,819 articles over the 20-year period. Sorting by subject heading determined the number of articles published each year under each heading (Figure 3).

- - - Insert Figure 3 about here - - -

The data shows that media attention on corporate issues increased from 1999 onwards after the acquisition of Safmarine and Sea-Land and the release of the UN Global Compact. In 2001 we note an increase related to the Mærsk Air incidence of non-compliance. In subsequent years there was increased focus on labor issues corresponding to incidents in El Salvador, Honduras and Nicaragua with peaks in 2007 and 2009 related to the Mumbai events. We note a certain persistency in reported events with a slight downward trend from 2009 when the APMM group signed the UN Global Compact. The number of publicly reported incidents corroborates the preceding analysis.

\section{Theoretical implications}

The literature presents a potential conundrum between economic rationales and ethical motivations for corporate responsible behaviors. Harrison and Freeman (1999) distinguish between stakeholder concerns and social responsibility for "economic reasons" or for "intrinsic merit" (p. 479). Waldman and Siegel (2008) express the same tension between "profit-maximizing CSR" (p. 118) where CSR investments are determined through cost-benefit analysis and corporate "actions based

\footnotetext{
${ }^{9}$ Infomedia is a primary provider of media intelligence in Denmark for advanced media search, media monitoring and media analysis.
} 
on moral values" (p. 121). However, the case analysis shows that these views are not contradictions. The decision to convert the tanker fleet into double hulled ships was arguably the right moral decision as it reduced the potential for environmental disasters. But it was also a rational decision to advance technological capabilities ahead of the competition envisioning a long-term trend towards tougher regulations. An ex ante cost-benefit analysis would obviously be challenged by highly uncertain regulatory regimes and the future value of environmental investments. The situation around the Mumbai labor conflict similarly illustrates circumstances where the complexity of the situation defies rational analysis. But it is exactly under such conditions that corporate values can guide managerial decisions (e.g., Camerer and Vepsalainen, 1988).

Campbell (2007) theorizes about the institutional factors that influence corporate responsible behavior including government regulation, industry self-regulation, social movements in the press, membership of professional associations, and key stakeholders. The case provides insight to these propositions. The decision to invest in double hull tankers was not driven by regulation but by a combination of moral and rational reasoning. One could argue that regulation primarily motivates laggards and not the proactive companies. Hence, the incident of failed compliance with EU competition rules was caused by lack of attention that surprised the corporate leadership.

While industry self-regulation may play a role, it did not seem to exert much influence on the APMM group. The presence of social movements and attention in the media clearly affected the treatment of the labor disputes where organizations like EIRIS pointed to seemingly irregular behaviors. The story also reveals highly perplexing circumstances around these situations with distorted public information where membership of a trade association had little influence. In contrast, the collaborative dialogue established with the ITF was instrumental in reaching a final 
solution to the Mumbai labor dispute. So, maintaining good relations with major stakeholders was instrumental for the ability to deal with emerging events.

From these insights we deduce that the value enhancing effect of corporate responsible behavior is related to conscious investment in positive economic externalities and not just to avoid negative economic externalities. Furthermore, the resulting effect on corporate reputation reflected in higher trust, accountability and reliability helped the company deal with complex emerging issues and find viable solutions (Figure 4). For example, the decision to invest in double hull tankers was a conscious investment in a positive economic externality to the benefit of society at large. This gained no immediate pay-off but created the reputation of a conscious industry player. The associated goodwill undoubtedly helped the company when Mærsk Air failed to comply with the EU competition rules. Similarly, when the Mumbai labor incident emerged, the APMM group used the ties to ITF in London, which eventually helped them find a solution to a highly complex dispute.

\section{- - - Insert Figure 4 about here - - -}

Increasing specialization, geographic dispersion and business diversification all add to the complexity and ambiguity of the global business environment. However, conscious investments in positive economic externalities create goodwill and improve the ability to deal with complex issues in the future. New trends in social norms, divergent national cultures and institutional frames influence decision makers in different parts of the world. Organizational factors like increased specialization and acquired businesses also distort the enforcement of consistent values and ethical principles. These behavioral divergences may cause inconsistent and dysfunctional practices across the company. However, investment in positive economic externalities can provide a better vantage point to develop viable collaborative solutions. 


\section{Discussion and conclusions}

The study demonstrates that increased internationalization of business activities combined with major acquisitions put new challenges on the ability to impose consistent moral principles on corporate activities. As the external pressures for socially responsible conduct increased a number of discrepant events were exposed in more distant geographical locations of company operations. It is observed how leadership imposed basic values through the execution of concrete business decisions whereas the unfolding of highly complex emerging events challenged a consistent pursuit of those values in a large complex multinational organization. Similar developments have been reported among other multinational companies (Tengblad and Ohlsson, 2009) calling for more formal approaches to sustain a corporate ethical identity across a broad global presence (Balmer, Fukukawa and Gray, 2007). These approaches often comprise an official code of conduct imposed through internal training and management development programs (Grojean et al., 2004; Van Lee, Fabish and McGaw, 2005).

The study describes an organizational learning process where the values are imprinted by concrete actions taken by leadership that display conscious care and timely responses while accepting mistakes as a way to improve current conduct. The learning processes entailed internal discussions across hierarchical and geographical boundaries supported by compliance-oriented training initiatives (Weaver, Trevino and Cochran, 1999). The particular experiences in this case illustrate how shortcuts rarely pay off and that a good reputation will carry the weight in the long run. According to Ane Mærsk Mc-Kinney Møller ${ }^{10}$ this coincides with one of her father's imprinted morals: "Don't be smart in the negative sense of the word. Don't go for the quick win if

\footnotetext{
${ }^{10}$ Ane Mærsk Mc-Kinney Uggla is the daughter of Mærsk Mc-Kinney Møller who after her father's death in 2012 assumed the chairmanship of the A.P. Møller and Chastine Mc-Kinney Møller Foundation that holds the controlling stake in the APMM group. She also serves as vice chairman of the APMM group board of directors.
} 
it isn't a sound option for the long run. Otherwise it may impact Our Name, the company." ${ }^{11}$ It is fair to ask whether this account presents a story of wishful thinking formed over time in the heads of the executive informants and enforced by a complicit public opinion. Parts of the storytelling literature suggest that stories espoused by people over time "are essential fulfilments of unconscious wishes" (Gabriel, 1991: p. 427). On the other hand stories transpose facts that even though embellished by values and emotions provide significant clues on "what people want to believe to have happened" (Gabriel, 1991: p. 429). The historical accounts of how the core values emerged in APMM may represent such aspects of storytelling that nonetheless were so strong and believable that they inspired and guided corporate decisions. This is conceivable because as Gabriel (1991: p. 436) argues, managers cannot impose "heroic stories" that will "be cynically dismissed" if there is deep mistrust in the management. In other words, it is quite plausible that espoused stories display a kernel of true values that management can be trusted to pursue in their decision-making.

In effect then, the corporate decision makers can be seen to accord specific values to ongoing decisions based on their assessment of experiences with past ethical conduct and perceived effects of responsible behaviors. Weick, Sutcliffe and Obstfeld (2005: p. 409) explain that "sensemaking involves the ongoing retrospective development of plausible images that rationalize what people are doing". So, the interplay between current actions and interpretation is important because it creates the identity that guides the decision-making. In other words, "plausible stories animate and gain their validity from subsequent activity" (Weick, Sutcliffe and Obstfeld, 2005: p. 410) and the stories are retained if their enactment lead to plausible outcomes. This view contravenes a pure positivist perspective that touts accurate scientific facts as the sole determinant of subsequent

\footnotetext{
${ }^{11}$ Quoted from 'The values are constant in a complex world', Interview (2014) Maersk Post (4): 6-10.
} 
qualitative outcomes. However, given the turbulent global conditions it is no longer a question of forming accurate forecasts from scarce information but rather a need to interpret a wealth of data and process it into "actionable knowledge" (Bettis and Prahalad, 1995). This is exactly where the values espoused in corporate storytelling can help guide the interpretive process in forwardlooking decision-making.

The field of narrative inquiry represents different strands that try to analyze accounts of sequenced complex events and occurrences that together reveal something significant (Brown, Gabriel and Gherardi, 2009). In this context it is important to gain diverse insights, e.g., "the vivid insights that a storytelling approach may yield need always to be complemented by other ways of seeing and understanding” (Brown, Gabriel and Gherardi (2009: p. 326). To this end we solicited direct evidence from interviews with key external stakeholders engaged in the events comprised by the corporate storytelling.

Storytelling can be seen as an ongoing process where the stories being told are influenced by an interpretive ante-narrative that leads towards a more general grand narrative going forward (Boje, 2001). The ante-narrative is a retrospective link to the story being told enforcing the core values of the organization and instigating generally accepted corporate behavior. However, organizations and the people operating them are immersed in complex unresolved issues and may have diverse storylines in different functions and locations. Trying to decompose these possibly divergent story lines may provide a basis to validate the observed official story. To this end we solicited inputs from diverse sources engaging various management groups in discussions to obtain a consistent interpretation of events.

The general study illustrates how leadership values were enforced through concrete executive decisions that drove corporate responsible behaviors emphasizing reliability, reputation and good 
relationships as a way to cope with unexpected risk situations (Husted, 2005; Kytle and Ruggie, 2005; Orlitzky and Benjamin, 2001). It provides evidence of how responsible behavior can have positive outcome implications in line with an embryonic empirical literature on the economic effects of social responsibility (Ambec and Lanoie, 2008; Sharfman and Fernando, 2008). The identified performance mechanic is manifested through conscious investment in positive economic externalities building future competencies and supporting a good reputation that enhances the ability to deal with emergent issues in an uncertain and unpredictable world. These insights are compatible with studies reporting that corporate social behavior is associated with lower business risk and higher returns (Orlitzky and Benjamin, 2001).

Freeman et. al (2010) argue that corporate leaders that enable products and services the customers like, with suppliers that like to deal with the firm, employees that want to work there, compete hard and fairly, and generally are good citizens then they display good business behavior. We add to this that such ethical conduct can be imposed by underlying leadership values enacted through concrete executive decisions and corporate actions. Conscious investment in positive economic externalities can create goodwill and enforce strong stakeholder relations that enhance the ability to deal with emerging events. The analyzed incidents illustrate how the core values influenced responsible behavior and supported stakeholder relationships for the long-term adaptability and survival of the corporation. The study also shows that diversification and global expansion can dilute those values and diverge behaviors and therefore must be taken into consideration in the multinational enterprise. 


\section{References}

Ambec, S. and P. Lanoie. 2008. Does it Pay to Be Green? A Systematic Overview, Academy of Management Perspectives 22(4): 45-62.

Andersen, T. J. 2011. The risk implications of multinational enterprise, International Journal of Organizational Analysis 19(1): 49-70.

Anderson, C. 1997. Values-Based Management, Academy of Management Executive 11(4): 25-46.

Balmer, J.M.T., Fukukawa, K. and E.R. Gray. 2007. The Nature and Management of Ethical Corporate Identity: A Commentary on Corporate Identity, Corporate Social Responsibility and Ethics, Journal of Business Ethics 76(1): 7-15.

Barry, D. and M. Elmes. 1997. On paradigm and narratives: Barry and Elmes' response, Academy of Management Review 22(4): 847-849.

Bartunek, J.M. 2007. Academic-Practitioner Collaboration Need not Require Joint or Relevant Research: Toward a Relational Scholarship of Integration, Academy of Management Journal 50: 1323-1333.

Bass, B.M.(1985). Leadership and Performance. Free Press: New York.

Bass, B.M. and B. J. Avolio (eds.). (1994). Improving Organizational Effectiveness through Transformational Leadership. Sage Publications: Thousand Oaks, CA.

Bass, B.M. and Steidlmeier. 1999. Ethics, character, and authentic transformational leadership behavior, Leadership Quarterly 10(2): 181-217.

Bazerman M. H. and D. A. Moore. 2009. Judgment in Managerial Decision Making (7th ed.). John Wiley: Hoboken, NJ.

Benson, P.S., Lambek, B. and S. Ørskov. 2004. Marsk-Manden og Magten. Politikens Forlag: København.Bettis, R.A. and C. K. Prahalad. 1995. The Dominant Logic: Retrospective and Extension, Strategic Management Journal 16: 5-14.

Boje, D. M. (2001). Narrative Methods for Organizational and Communication Research, Sage: London.

Barnard, C. I. 1968. The Functions of the Executive ( $30^{\text {th }}$ ann. edn.). Harvard University Press: Cambridge, MA. (first published in 1938).

Bower, J. 1970. Managing the Resource Allocation Process. Harvard Business School Press: Boston.

Bower, J. and C.G. Gilbert. 2005. From Resource Allocation to Strategy. Oxford University Press: New York.Brown, A. D., Gabriel, Y. and S. Gherardi. 2009. Storytelling and Change: An Unfolding Story, Organization 16(3): 323-333.

Burns, J.M. (1978). Leadership. Harper \& Row: New York.

Camerer, C. and A. Vepsalainen. 1988. The Economic Efficiency of Corporate Culture, Strategic Management Journal 9: 115-126.

Campbell, J.L. 2007. Why would corporations behave in socially responsible ways? An institutional theory of corporate social responsibility, Academy of Management Review 32(3): 946-967.

Campbell, J. T. 2012. Multinationals and corporate social responsibility in host countries: Does distance matter? Journal of International Business Studies 43: 84-106.

Carroll, A. B. 1999. Corporate social responsibility: Evolution of a definitional construct, Business \& Society 38: 268-295.

Cortzen, J. 2003. Myten Møller (6 $6^{\text {th }}$ ed.). Børsens Forlag: København. 
Deal, T. E. and A. A. Kennedy. 2000. Corporate Cultures: The Rites and Rituals of Corporate Life. Perseus Books Publishing: New York.

De Hoogh, A.H.B. and D.N. Den Hartog. 2008. Ethical and despotic leadership, relationships with leader's social responsibility, top management team effectiveness and subordinates' optimism: A multimethod study, Leadership Quarterly 19: 297-311.

Doh, J. P. and N. R. Quigley. 2014. Responsible leadership and stakeholder management: Influence pathways and organizational outcomes, Academy of Management Perspectives 28(3): 255-274.

Dutton, J.E., Ashford, S.J., O’Neill, R.M., and K.A. Lawrence. 2001. Moves that matter: Issue selling and organizational change, Academy of Management Journal 44(4): 716-736.

Freeman, R. E. 1984. Strategic Management - A Stakeholder Approach. Cambridge University Press: Cambridge.

Freeman, R. E., Harrison, J. S., Wicks, A. C., Parmar, B. L. and S. De Colle. 2010. Stakeholder TheoryThe State of The Art. Cambridge University Press: Cambridge.Gabriel, Y. 1991. On Organisational Stories and Myths: Why it is Easier to Slay a Dragon Than to Kill a Myth, International Sociology 6(4): 427-442.

Gehman, J. Trevino, L. K. and R. Garud. 2013. Values work: A process study of the emergence and performance of organizational values practices, Academy of Management Journal 56(1): 84-112.

Hanke, T. and W. Stark. 2009. Strategy Development: Conceptual Framework on Corporate Social Responsibility, Journal of Business Ethics 85(3): 507-516.

Harrison, J. S. and R. E. Freeman. 1999. Stakeholders, social responsibility, and performance: Empirical evidence and theoretical perspectives, Academy of Management Journal 42(5): 479-485.

Hooijberg, R., Lane, N. and Diversé, A. 2010. Leader effectiveness and integrity: Wishful thinking? International Journal of Organizational Analysis 18(1): 59-75.

Hornby, O. 1988. “With Constant Care ...” A. P. Møller: Shipowner 1876-1965. Schultz: Copenhagen.

Hemingway, C. A. and P. W. Maclagan. 2004. Managers' Personal Values as Drivers of Corporate Social Responsibility, Journal of Business Ethics 50: 33-44.

Husted, B.W. 2005. Risk Management, Real Options, and Corporate Social Responsibility, Journal of Business Ethics 60: 175-183.

Kytle, B. and J.G. Ruggie. 2005. Corporate Social Responsibility as Risk Management: A Model for Multinational', Corporate Social Responsibility Initiative Working Paper No. 10. John F. Kennedy School of Government, Harvard University: Cambridge, MA.

Grojean, M.W., Resick, C.J., Dickson, M.W. and D.B. Smith. 2004. Leaders, Values, and Organizational Climate: Examining Leadership Strategies for Establishing an Organizational Climate Regarding Ethics, Journal of Business Ethics 55(3): 223-241.

Jensen, L. 2014. Culture Shock in Maersk Line: From Entrepreneurs and Kings to Modern Efficiency, Vespucci Maritime Publishing: Copenhagen.

Lindholm, M. and D. Stokholm. 2011. Marsk - Ledelse i Verdensklasse. Gyldendal Business:

København.

Lovallo, D. and D. Kahneman. 2003. Delusions of Success: How Optimism Undermines Executives' Decisions, Harvard Business Review 81(7): 56-63.

Lunde, N. 2008. Hr. Mфllers nye mand - Nils Smedegaards revolution på Esplanaden - og på Carlsberg. Jyllands-Postens Forlag: København. 
Mintzberg, H. 1978. Patterns in Strategy Formation, Management Science 24(9): 934-948.

Mintzberg, H. and J.A. Waters. 1985. Of strategies, Deliberate and Emergent, Strategic Management Journal 6: 257-272.

Nielsen, R.P. 2009. Practitioner-Based Theory Building in Organizational Ethics, Journal of Business Ethics 93(3): 401-406.

Orlitzky, M. and J.D. Benjamin. 2001. Corporate Social Performance and Firm Risk: A Meta-Analytic Review, Business \& Society 40(4): 369-396.

Schaubroeck, J. M., Hannah, S. T., Avolio, B. J., Kozlowski, S. W. J., Lord, R. G., Trevino, L. K., Dimontakis, N. and A. C. Peng. 2012. Embedding ethical leadership within and across organization levels, Academy of Management Journal 55(5): 1053-1078.

Schein, E. H. 2004. Organizational Culture and Leadership. Jossey-Bass: San Francisco, CA.

Sharfman, M. P. and C.S. Fernando. 2008. Environmental Risk Management and the Cost of Capital, Strategic Management Journal 29: 569-592.

Siegel, D. S. 2014. Responsible leadership, Academy of Management Perspectives 28(3): 221-223.

Simons, R. 1995. Levers of Control: How Managers Use Control Systems to Drive Strategic Renewal. Harvard Business School Press: Boston, MA.

Tengblad, S. and C. Ohlsson. 2009. The Framing of Corporate Social Responsibility and the Globalization of National Business Systems: A Longitudinal Case Study, Journal of Business Ethics 93(4): 653-669.

Tetlock, P. C., Saar-Tsechansky, M. and S. Macskassy. 2008. More than words: Quantifying language to measure firms' fundamentals, Journal of Finance 63(3): 1437-1467.

Trevino, L. K. 1986. Ethical Decision Making in Organizations: A Person-Situation Interactionist Model, Academy of Management Review 11(3): 601-617.

Uotila, J., Maula, M. Keil, T. and A. Z. Shaker. 2009. Exploration, exploitation, and financial performance: Analysis of S\&P 500 corporations, Strategic Management Journal 30: 221-231.

Van Knippenberg, D. and Sitkin, S. B. (2013). A critical assessment of charismatic-transformational leadership research: Back to the drawing board? The Academy of Management Annals 7(1): 1-60.

Van Lee, R., Fabish, L. and N. McGaw. 2005. The Value of Corporate Values, Strategy+Business 39: 823-837.

Waldman, D.A. and D. Siegel. 2008. Defining the socially responsible leader, Leadership Quarterly 19: 117-131.

Waldman, D. A., Sully de Luque, M., Washburn, N. and R. J. House. 2006. Cultural and Leadership Predictors of Corporate Social Responsibility Values of Top Management: A GLOBE Study of 15 Countries, Journal of International Business Studies 37: 823-837.

Waldman, D. A. and R. M. Balven. 2014. Responsible leadership: Theoretical issues and research directions, Academy of Management Perspectives 28(3): 224-234.

Wang, H., Barney, JB. and J. Reuer. 2003. Stimulating firm-specific investment through risk management, Long Range Planning 36(1): 49-59.

Weaver, G.R., Trevino, L.K. and P.I. Cochran. 1999. Corporate Ethics as Control Systems: Influences of Executive Commitments and Environmental Factors, Academy of Management Journal 42(1): 41-57. 
Weick, K. E., Sutcliffe, M. and D. Obstfeld. 2005. Organizing and the Process of Sensemaking, Organization Science 16(4): 409-421.

Wieland, J. 2005. Corporate Governance, Values Management, and Standards: A European Perspective, Business \& Society 44: 74-93.

Yin, R. K. 2003. Case Study Research: Design and Methods ( $3^{\text {rd }}$ ed.). Sage Publications: Thousand Oaks, CA. 
Figure 1. A Deductive Model of Corporate Responsible Behavior and Its Effects

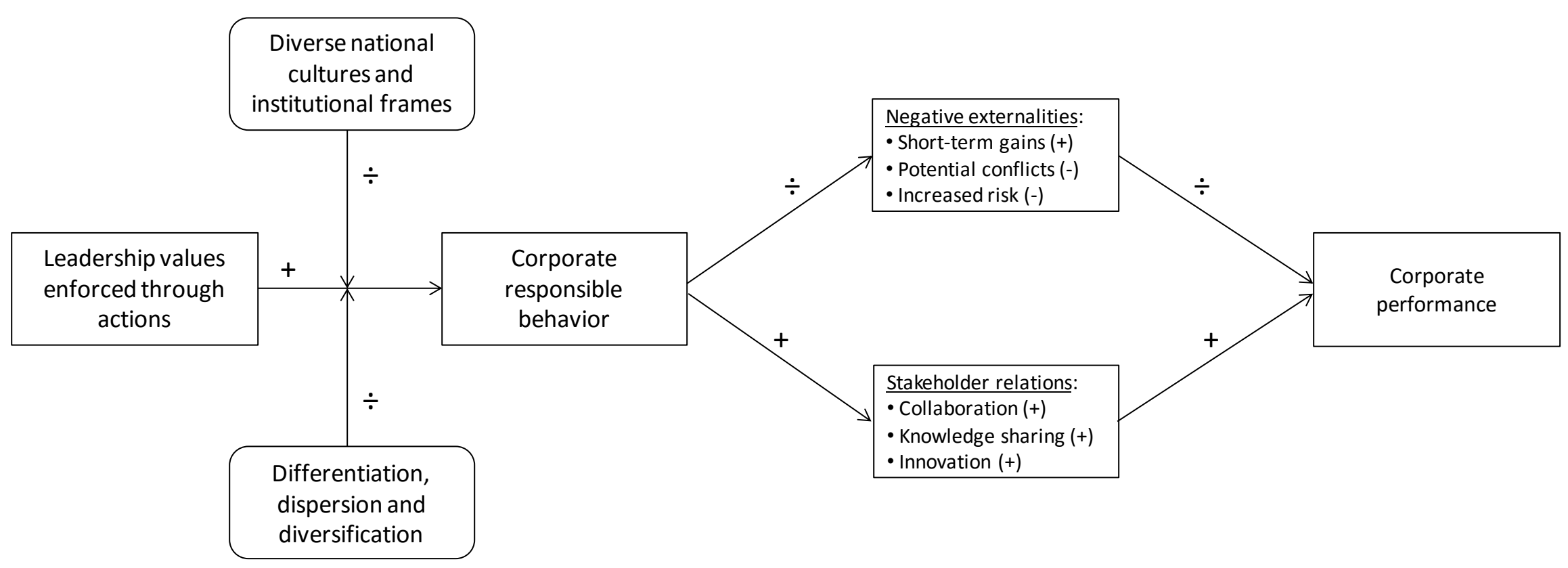




\section{Figure 2. A Timeline of Corporate Leadership Developments 1904-2005}

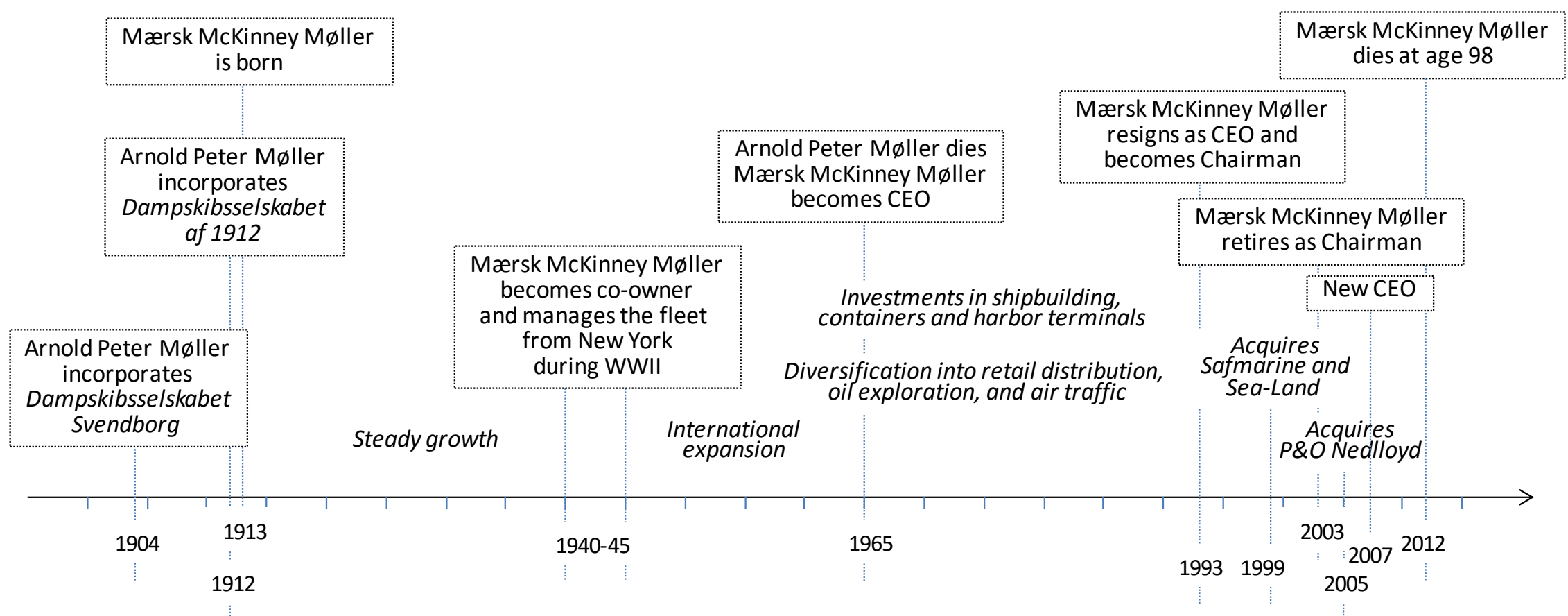


Figure 3. Events Reported in the Press 1994-2014

(number of articles registered per year per subject heading)

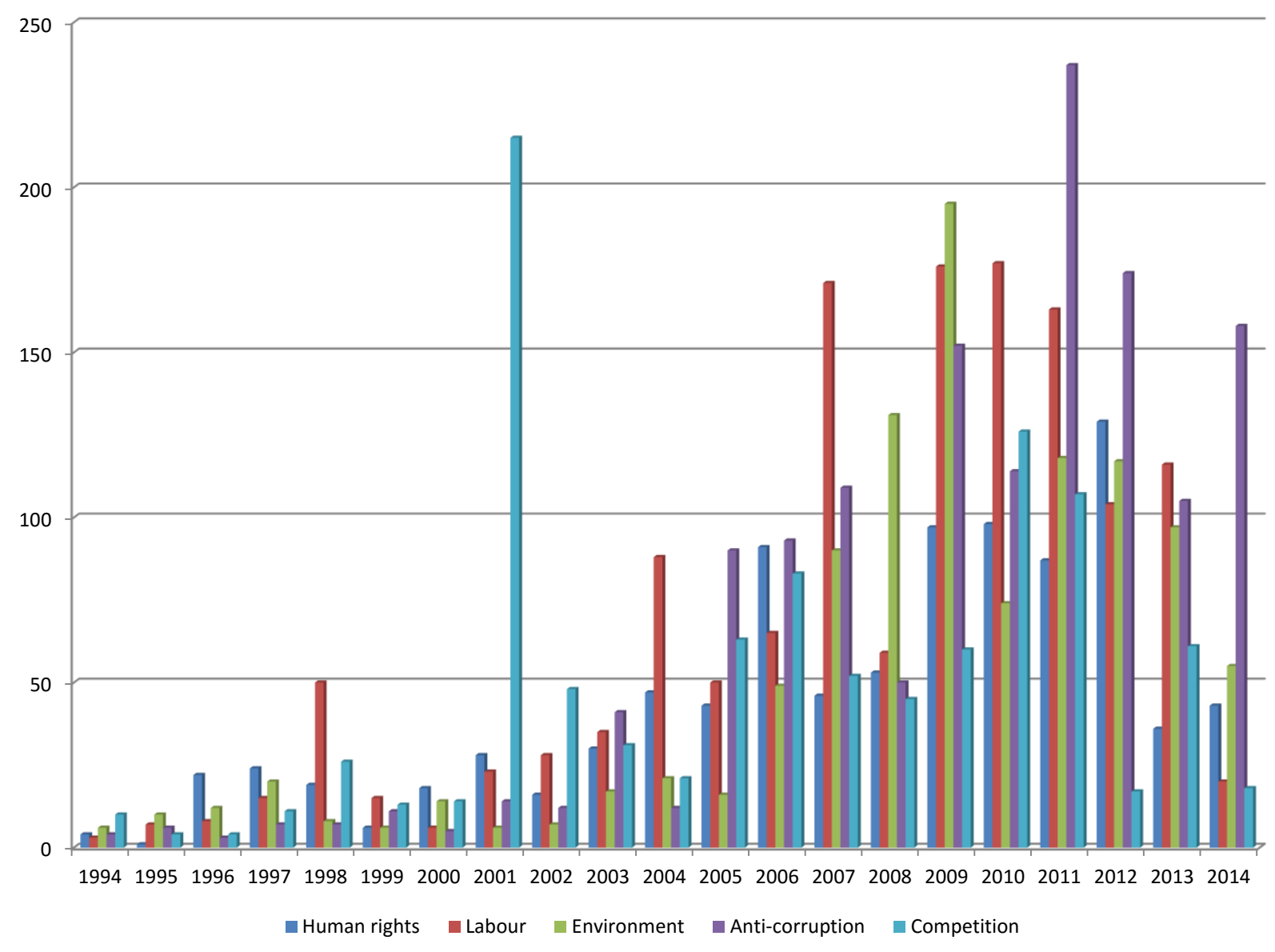


Figure 4. An Updated Performance Model of Corporate Responsible Behavior

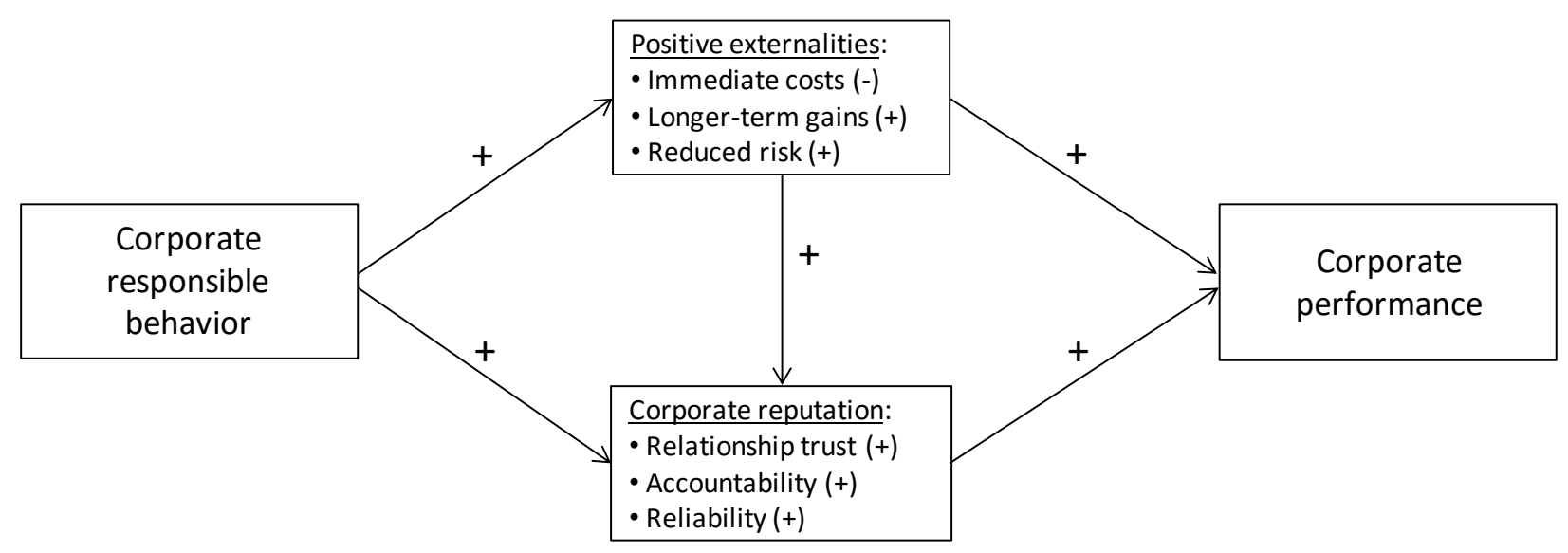




\section{APPENDIX 1}

\section{Mærsk - Our Values}

\section{Our Values}

Shaping the way we do business.

\section{Constant Care}

Take care of today, actively prepare for tomorrow

What it means as a core value:

Forward thinking, planning and execution

Being informed, innovative and seeking out new ideas

Looking for changes in the environment

\section{Humbleness}

Listen, learn, share, and give space to others.

What it means as a core value:

Showing trust and giving empowerment

Havinf an attitude of continuous learning

Never underestimating our competitors or other stakeholders

\section{Uprightness}

Our word is our bond.

What it means as a core value:

Honesty and accountability

Openness about the good and the bad

Speaking your mind in the debate, but backing the decision

\section{Our Employees}

The right environment for the right people.

What it means as a core value:

Attarcting and retaining the right people, building the right team

Providing opportunities for continual development

Rewarding performance, promoting for potential

\section{Our Name}

The sum of our values: passionately striving higher.

What it means as a core value:

The embodiment of our values

Passion and pride for what we do and how we do it

Our image in the eyes of our customers and the external world

Source: The A. P. Møller-Mærsk Group website 


\section{APPENDIX 2}

\section{UN Global Compact}

\section{The Ten Principles}

\section{Human Rights}

1. Business should support and respect the protection of internationally proclaimed human rights

2. Businesses should make sure that they are not complicit in human rights abuses

\section{Labour}

3. Businesses should uphold the freedom of association and the effective recognition of the right to collective bargaining

4. Businesses should eliminated all forms of forced and compulsory labor

5. Businesses should effectively abolish child labor

6. Businesses should eliminate discrimination in respect of employment and occupation

Environment

7. Businesses should support a precautionary approach to environmental challenges

8. Businesses should undertake initiatives to promote greater environmental responsibility

9. Businesses should encourage the development and diffusion of environmentally friendly technologies

Anti-corruption

10. Businesses should work against corruption in all its forms, including extortion and bribery

Source: The United Nations website [ http://www.unglobalcompact.org ] 


\section{End Notes}

${ }^{i}$ After the Exxon Valdez ran aground in 1989, the U.S. authorities introduced the Oil Pollution Act of 1990 (OPA 90) requiring new oil tankers to be double hulled while phasing out the old single hull tankers between 1995 and 2015. Other requirements were imposed outside the US in 1993 by the International Maritime Organization (IMO) as Annex I to the international convention for the prevention of pollution from ships (MARPOL) whereby all large single hull tankers would be phased out by 2026. However, subsequent to the sinking of the Erika off the French coast in 1999 the MARPOL rules were amended with effect from September 2002 to accelerate the phase out of single hull tankers by 2015. Similar regulation to accelerate the in-phasing of double hull designs was also imposed within the EU during 2002.

ii International maritime regulation seeks to impose common standards on shipping transportation to ensure efficiency in international trade. The shipping industry is primarily regulated by a UN agency, the International Maritime Organization (IMO), established to protect the marine environment, safety, and labor standards at sea. The regulations are governed by diplomatic conventions agreed by the member countries. The rules are imposed by the flag states where ships are registered and port state controls at the harbors the ships visit. The IMO was instituted at an international conference in Geneva and put into force in 1958. The International Labor Organization (ILO), another UN agency, bridges the views of governments, employers, and workers to safeguard working conditions at sea. Historically the global shipping industry has been characterized by collusive arrangements where the shipping firms met at conferences to set freight rates and coordinate schedules and exclusive regional coverage. These conferences came under more intense scrutiny and have been challenged, e.g., in US courts, as well as by UN guidelines for liner conferences with effect from 1983 to ensure broader representation. The adverse effects of restrictive price and market conferences have received more recognition and are now succumbed to national anticollusive legislation and enforcement efforts.

iii The competition laws of the European Union are aimed to counter abuse of market power by major corporations to the detriment of economic welfare. Hence, the EU treaties have provisions to ensure that competition prevails and cartel agreements and monopolistic price fixing are avoided quite comparable to the US antitrust laws. Articles 101 and 102 of the Treaty on the Functioning of the European Union (TFEU) deal with collusion, anti-competitive practices, and abuse of dominant market positions while giving the Commission authority to enforce the competition laws within the EU. The Directorate-General (DG) for Competition was responsible for implementing the competition policies within the EU while enforcing the antitrust regulations. Mario Monti was Commissioner in charge of the DG from 1999 to 2004.

iv The Ethical Investment Research Services (EIRIS) conducted independent research on corporate responsibility and sustainability for investors - a service used by Arbejdsmarkedets Tillægs-Pension (ATP), the largest institutional investor in Denmark and an important APMM shareholder. EIRIS made formal requests to the APMM group regarding allegations that the firm failed to uphold collective bargaining rights and freedom to organize among employees in its US and Central American divisions with reference to 'corporate codes of conduct' setting minimum standards for working conditions in line with ILO conventions.

${ }^{v}$ It is interesting to note that throughout the period of these episodes, GTI continued to win professional prices and awards recognizing the operational efficiency of the facilities. These included, e.g., 'Port of the Year' (Lloyd's List), 'Smart Workplace' (Economic Times), 'Container Terminal of the Year' (CNBC India), 'Safest Terminal', 'Container Terminal of the Year' (IIMLE), etc. In other words, the company did not operate with outdated facilities but had invested in modern terminals incorporating state-of-the-art technology. 
Acknowledgements: The support from the CBS Office for Responsible Management Education (PRME) is highly appreciated. Christine Bang Andersen provided very competent research assistance. I thank Kai Hockert for his engagement at the early stages of the project and Peter Ping Li for thoughtful comments. Participants at the Nordic Symposium for Corporate Social Responsibility, counting R. Edward Freeman, made good suggestions to an early draft. Stuart Howard (ITF), Dawn McLaren (EIRIS), Klaus Wiinblad (ATP) and Annette Stubbe (APMM) made valuable contributions along the way. A special appreciation goes to Knud Pontoppidan for his ongoing encouragement and support to this project. 